\begin{tabular}{c} 
International Journal of Engineering \& Technology, $7(2.13)(2018) 410-412$ \\
International Journal of Engineering \& Technology \\
SPC \\
Website: www.sciencepubco.com/index.php/IJET \\
Research Paper \\
\hline
\end{tabular}

\title{
Designing an Augmented Reality Strategy: ELearning/ Extensive Reading
}

\author{
Lusy Tunik Muharlisiani ${ }^{1}$, Nuning Kurniasih ${ }^{2}$, Lilik Istiqomah ${ }^{3}$, Rizka Safriyani $^{4}$, Nuskhan Abid ${ }^{5}$, \\ Yulia Rizki Ramadhani ${ }^{6}$, Salmon James Hukom ${ }^{7}$, Basar Lolo Siahaan ${ }^{8}$, Edy Anas Ahmadi ${ }^{9}$, Erna Hendrawati ${ }^{10}$ \\ Department of English Education, Universitas Wijaya Kusuma, Surabaya, Indonesia \\ ${ }^{2}$ Faculty of Communication Sciences, Library and Information Science Program, Universitas Padjadjaran, Bandung, Indonesia \\ ${ }^{3}$ Department of English Education, IAIN Surakarta, Surakarta, Indonesia \\ ${ }^{4}$ Department of English Education, UIN Sunan Ampel, Surabaya, Indonesia \\ ${ }^{5}$ IAIN Kudus, Indonesia \\ ${ }^{6}$ Department of English Education, Universitas Graha Nusantara Padangsidimpuan, Indonesia \\ ${ }^{7}$ Department of English, Universitas Pattimura, Indonesia \\ ${ }^{8}$ Department of English, Universitas HKBP Nommensen, Indonesia \\ ${ }^{9}$ Universitas Islam Lamongan, Indonesia \\ ${ }^{10}$ Department of Accounting, Universitas Wijaya Kususma, Surabaya, Indonesia \\ *Corresponding author E-mail: lusytm_fbs@uwks.ac.id
}

\begin{abstract}
This paper aims to see the students' responses toward the use of Augmented Reality in English learning as the application has been used in some courses in some levels of students in UWKS. The study implemented the quasi-experimental methodology by applying for the program to two groups, controlled and experimental. Survey method along with the use of questionnaire was used for data collection. The finding and discussion showed that Augmented Reality was well -utilized in the activity of English language teaching. However, the utilization needed to be more optimized and explored due to most of them were first time users.
\end{abstract}

Keywords: Design; Interactive Learning; Augmented Reality; Extensive Reading; E-Learning' Information Technology

\section{Introduction}

The Augmented Reality (AR) in this study is defined operationally as making integration between the virtual reality through images, shapes with the actual fact for the learners in a way that enables them to gain the subject competences more efficient. AR related to the perception of the user in arguing or modifying the real world. According to Azuma [1], AR includes three elements, namely how real and virtual objects join the real world; runs interactively in real time; aligning real objectives with virtual.

In this digital era, the range of technologies is available for use in language learning and teaching. They are being used in classrooms all over the world to make language learning and teaching more challenging and exciting. The desired learning outcome has long been examined. Overviewing the postulation by Banados[2], Beauvois[3], and Nuning Kurniasih et.al. [4], [5] which premise that technology plays an essential role in creating new learning media to produce an excellent learning environment, where learning is not only one way communication, but also can run interactively, lead me into an implementation of media development in teaching

Some research findings present a massive improvement in the evolution of teaching and learning activities. English teaching in Indonesia has many challenges since English, as a foreign language, requires innovative teaching strategies, tools, and media. It is applied in an Extensive Reading class where students present. Each student was assigned to read a book, report it orally, and, while the other students listen and leave a comment on it. Therefore, it created fun learning and encouraged students to learn how to communicate review orally and look well to other student's evaluation.

In teaching extensive reading, this study focused on investigating the efficiency of using Augmented Reality for Extensive Reading compared to conventional corrective feedback methods. To examine if AR form of corrective feedback could be introduced, an experimental design is created wherein the fourth-semester students are placed in a large reading room. They were divided into two groups, namely the control group and the experimental group. The results show that AR feedback should be integrated into extensive reading on teaching and learning to be more efficient.

This paper aims to see the students' responses toward the use of Augmented Reality in English learning as the application has been used in some courses in some levels of students in UWKS. Or to see the impact of it. Elaborated qualitatively, this paper shows you how much students get into the learning. It is shown that even though self-effort to internet access was the main obstacle in the teaching, their reading is found improved. This result in the future is expected to be able to make other faculties realize that AR application can enhance the learning environment and outcome. 


\section{Method}

The study implemented the quasi-experimental methodology by applying for the program on two groups, controlled and experimental. The data analysis revealed an improvement of students' performance in learning English in the experimental group than their peers in the controlled group, which indicates the effectiveness of designed program (1) offer a teaching program that is based on Augmented Reality to teach the learning competencies of English as a foreign language; (2) determine the effectiveness of the Augmented Reality program in teaching English; (3) recommend ways to improve the utilization of computer in the teachinglearning process when teaching English as a foreign language Most of the researches prove that this method is a feasible method to improve the students' extensive reading. Liaw [6] investigated the use of online task-based activities in a process-oriented extensive reading class. The results showed that students were able to produce more complex syntax and lexical essays.

Survey method along with the use of questionnaire was used for data collection. The questionnaire was administered using Augmented Reality. The population was 100 students who were taught using AR. Based on Cohen et al., [7 ] the more significant the sample out of the population, the better it is, and yet the minimum size must not be less than 30 sample. In harmony with that, Gay in Nagel [8] declared that the minimum sample size for research is: a. Descriptive method, minimum $10 \%$ out of the population. For a relatively small community, $20 \%$ sample is the least; b. Correlational descriptive method, minimum of 30 subjects. c. Ex post facto method, minimum of 15 subjects per group d. Experimental method minimum 15 subjects per group. To improve the extensive reading by using $A R$, the first thing to do is to design an interesting, meaningful and effective task. This study conducted a learning performance analysis, correlation analysis, and qualitative content analysis of the learning process of 30 participants who are enrolled in an extensive reading course. The results indicate that the learners improved their extensive reading and. through roleplaying activities and the learning tools.

The topic was about personal reading, and it took three of fourteen meetings in one semester. The following are the detail activity. According to Yeh \& Lo [9]

\begin{tabular}{|c|c|c|c|}
\hline Meeting & July 5, 2018 & $\begin{array}{ll}\text { July } & 12, \\
2018 & \end{array}$ & $\begin{array}{l}\text { September } \\
26,2018\end{array}$ \\
\hline Topic & $\begin{array}{l}\text { Personal } \\
\text { Reading }\end{array}$ & $\begin{array}{l}\text { Book } \\
\text { view }\end{array}$ & $\begin{array}{l}\text { Book } \\
\text { view }\end{array}$ \\
\hline Activities & $\begin{array}{l}\text { The students } \\
\text { were required } \\
\text { to find their } \\
\text { favorite books } \\
\text { and bring them } \\
\text { to the follow- } \\
\text { ing meeting. } \\
\text { The lecturer } \\
\text { explained } \\
\text { that they } \\
\text { were as- } \\
\text { signed to do } \\
\text { an oral re- } \\
\text { view of their } \\
\text { books }\end{array}$ & $\begin{array}{l}\text { The students } \\
\text { discussed } \\
\text { their books. } \\
\text { The students } \\
\text { were assigned } \\
\text { to read their } \\
\text { books for two } \\
\text { weeks, rec- } \\
\text { orded the oral } \\
\text { review and } \\
\text { posted on } \\
\text { Augmented } \\
\text { Reality. } \\
\text { The stu- } \\
\text { dents learned to } \\
\text { work with } \\
\text { Augmented } \\
\text { Reality }\end{array}$ & $\begin{array}{l}\text { The students } \\
\text { finished read- } \\
\text { ing and pre- } \\
\text { pared oral } \\
\text { book review. } \\
\text { They upload- } \\
\text { ed it to their } \\
\text { Augmented } \\
\text { Reality. } \\
\text { The reviews } \\
\text { posted on } \\
\text { Augmented } \\
\text { Reality should } \\
\text { be listened to } \\
\text { by all stu- } \\
\text { dents. They } \\
\text { were encour- } \\
\text { aged to leave } \\
\text { comments on } \\
\text { friends' re- } \\
\text { view }\end{array}$ \\
\hline $\begin{array}{l}\text { Lecturer's } \\
\text { role }\end{array}$ & $\begin{array}{l}\text { The lecturer } \\
\text { reminded stu- } \\
\text { dents to find } \\
\text { the most favor- } \\
\text { ite book and }\end{array}$ & $\begin{array}{l}\text { The lecturer } \\
\text { checked each } \\
\text { student's } \\
\text { book and } \\
\text { made sure }\end{array}$ & $\begin{array}{l}\text { In class, the } \\
\text { lecturer } \\
\text { checked stu- } \\
\text { dents' work } \\
\text { by scrutiniz- }\end{array}$ \\
\hline
\end{tabular}

\begin{tabular}{|c|c|c|c|}
\hline & $\begin{array}{l}\text { explained how } \\
\text { to prepare } \\
\text { book review } \\
\text { and assert } \\
\text { some guide- } \\
\text { lines and all } \\
\text { the things re- } \\
\text { lated to a book } \\
\text { review }\end{array}$ & $\begin{array}{l}\text { that every } \\
\text { student } \\
\text { brought the } \\
\text { favorite book. } \\
\text { The lecturer } \\
\text { also intro- } \\
\text { duced Aug- } \\
\text { mented Reali- } \\
\text { ty, the fea- } \\
\text { tures and how } \\
\text { to work with } \\
\text { it }\end{array}$ & $\begin{array}{l}\text { ing their } \\
\text { Augmented } \\
\text { Reality. } \\
\text { Outclass, the } \\
\text { lecture eval- } \\
\text { uated stu- } \\
\text { dents works } \\
\text { and checked } \\
\text { the com- } \\
\text { ment left in } \\
\text { each review. }\end{array}$ \\
\hline $\begin{array}{l}\text { Students' } \\
\text { role }\end{array}$ & $\begin{array}{l}\text { In class, the } \\
\text { students made } \\
\text { notes on the } \\
\text { lecturer's ex- } \\
\text { planation about } \\
\text { how to prepare } \\
\text { book review. } \\
\text { Outclass, the } \\
\text { students found } \\
\text { most loved } \\
\text { books to read } \\
\text { and review }\end{array}$ & $\begin{array}{l}\text { The lecturer } \\
\text { checked each } \\
\text { student's } \\
\text { book and } \\
\text { made sure } \\
\text { that every } \\
\text { student } \\
\text { brought the } \\
\text { favorite book. } \\
\text { The lecturer } \\
\text { also intro- } \\
\text { duced Aug- } \\
\text { mented Reali- } \\
\text { ty, the fea- } \\
\text { tures and how } \\
\text { to work with } \\
\text { it }\end{array}$ & $\begin{array}{l}\text { In class, The } \\
\text { Students had a } \\
\text { look at their } \\
\text { works on } \\
\text { Augmented } \\
\text { Reality. They } \\
\text { visited other } \\
\text { students re- } \\
\text { view and lis- } \\
\text { tened. } \\
\text { Outclass, the } \\
\text { students } \\
\text { continued to } \\
\text { listen to } \\
\text { other friends } \\
\text { review and } \\
\text { left a com- } \\
\text { ment }\end{array}$ \\
\hline
\end{tabular}

Meanwhile, to monitor students' activity, lecturer's evaluation sheet was used. There were some points, which were noted, i.e., students' oral review posted in Augmented Reality, the number of comments left by other students and how the comments were gone. The number of comment referred to how each student was

\section{Result And Discussion}

According to the result of the questionnaire, it was seen that $40,5 \%$ of students agreed that learning English using Augmented Reality was exciting and challenging. Meanwhile, $37,8 \%$ of students slightly decided that it was easy for them to use it. Since it was their first time using Augmented Reality, they needed to adjust how to create an account and explore its functions. 59,9\% of students agreed that posting an oral book review on their Augmented Reality account was helpful. It helped them to communicate and share the story. When they were assigned to listen to another friend review, $62,2 \%$ of students agreed that the review was understandable and $40,5 \%$ of students came to an agreement that listens to oral book review through Augmented Reality was so fun It can be seen from the way they left a comment and the content. Leaving a comment on friends' review did not make any problem, $37.8 \%$ of students slightly agreed that it was not difficult for them to post comments. Meanwhile, $35,1 \%$ of students agreed that they could read English book better by preparing a book review. Also, the students admit that they did not have any problem when they came to communicate the review. $59,5 \%$ of students agreed with that. Last but not least, $45,9 \%$ of students agreed on getting an opportunity to learn how to respond well when they listened to their friend oral book review. However, the number of participants who get involved in the discussion was less than the total number of student.

Based on the finding, the result of questionnaire revealed students' perspective on using AR; the result showed that this new platform attracted and challenged 19 of 30 students. It derived from $40,5 \%$ students who agreed and $24,3 \%$ who strongly agreed on these points. While the other 11 students were less attracted and challenged. 14 students, who agreed and strongly agreed that AR was easy, supported this condition. 16 students did not admit yet that AR was easy. They need time to get to know better and explore 
more on the features and functions. In this case, the lecturer should spend the specific time to guide, discuss, and give enough time for students to explore.

Meanwhile, according to the result of the second section and the lecturer evaluation sheet, the implementation of AR as a platform especially for communicating the oral book review showed positive advantages. The students who posted the review got a positive opportunity in conveying obtained information about interesting the curiosity came up among them. Therefore, this activity can enable to improve students' reading habit

By implementing ICT in the classroom, the process of teaching and learning becomes more alive and interactive. It motivates students during the activities and stimulates students to be creative by doing computer-based activities[10]. The massive use of internet in our society gives us the opportunity to develop the strategy of teaching and learning. Teachers or lecturers do not depend on old method anymore while the technology is overgrowing. They create a virtual environment, which enlarges the networking and encourages the creativity.

Based on the above, it can be concluded that Augmented Reality concept consists of individual elements, such as the virtual reality that is linked to the actual fact of the learner, and technological devices that facilitate the existence of images and interaction in a 3D model. To conclude, conducting lessons by using technology is believed to add more interaction and fun to the learning process for these young learners, especially those who study English as a foreign language as learners in this regard will need to get exposed to new teaching styles, new devices, and facilities that match with their characteristics, especially that most families today own smart devices, such as mobile phones. This study aims to find a correlation between academic achievement with the level of motivation in Language class by using AR. The results of the study show that AR technology provides a significant positive relationship between academic performance and motivation of undergraduate students in Language classes, especially in vocabulary learning.

\section{Conclusion}

The finding and discussion showed that Augmented Reality was well -utilized in the activity of English language teaching. The students were able to access although not all students could do that well due to their familiarity towards that platform. Whereas, the operation of AR is easily accessible and they do not need to pay for the access since it is free. However, the utilization needed to be more optimized and explored due to most of them were first time users. It was seen from the result of the questionnaire where $37,8 \%$ or 11 students slightly agree towards the access of Augmented Reality. According to the result of the discussion, some recommendations are proposed. First, lecturer-students should set a certain time to get to know what AR is and exploring its features and functions better. Second, prepare well the lesson plan and scrutinize the activities, which enable to optimize more the operation of AR. Last but not least, creating AR group is prominent to maintain the activity, observe and evaluate the activity of English language teaching

Based on the results obtained in this study, it can be concluded that using Augmented Reality in designing program for learning English for cycle one students in the elementary stage can facilitate their learning more and assist those students to gain the required learning competencies in this regard more easily and quickly. Also, the experimental group shows how Augmented Reality supported those students to be active participants in the class and get engaged when learning the foreign language.

(1) Encourage the learning institutes and teachers of English to apply the Augmented Reality in designing and presenting their lessons for students in the elementary stage as it helps in engaging students and raise their motivation towards learning the target language and encourage the government based on their APBD to empower the education[11], [12]; (2) Conduct workshops and training sessions for teachers to train them on how to use Aug- mented Reality in designing and presenting their lessons; (3) Reconsider the currently used learning materials and substitute them with others that are designed according to Augmented Reality

\section{References}

[1] R. Azuma, Y. Baillot, R. Behringer, S. Feiner, S. Julier, and B. MacIntyre, "Recent advances in augmented reality," IEEE Comput. Graph. Appl., vol. 21, no. 6, pp. 34-47, 2001.

[2] E. Banados, "A blended-learning pedagogical model for teaching and learning EFL successfully through an online interactive multimedia environment," CALICO J., pp. 533-550, 2006.

[3] C. Teixeira and D. Gomes, "Insights into learning profiles and learning outcomes within introductory accounting," Account. Educ., vol. 26, no. 5-6, pp. 522-552, 2017.

[4] N. Kurniasih et al., "Prototype Application Hate Speech Detection Website Using String Matching and Searching Algorithm," Int. J. Eng. Technol., vol. 7, no. 2.5, pp. 62-64, 2018.

[5] S. Rahayu, N. Ulfatin, B. B. Wiyono, A. Imron, and M. B. N. Wajdi, "The Professional Competency Teachers Mediate the Influence of Teacher Innovation and Emotional Intelligence on School Security," J. Soc. Stud. Educ. Res., vol. 9, no. 2, pp. 210 227, 2018 .

[6] C. Liaw, H. Hoenigschmid, M. Dimitrova, and M. Angerbauer, "Methods for generating a reference voltage and for reading a memory cell and circuit configurations implementing the methods." Google Patents, 11-Mar-2008.

[7] L. Cohen, L. Manion, and K. Morrison, Research methods in education. routledge, 2002.

[8] L. Nagel and T. G. Kotzé, "Supersizing e-learning: What a CoI survey reveals about teaching presence in a large online class," Internet High. Educ., vol. 13, no. 1-2, pp. 45-51, 2010.

[9] S.-W. Yeh and J.-J. Lo, "Using online annotations to support error correction and corrective feedback," Comput. Educ., vol. 52, no. 4, pp. 882-892, 2009.

[10] N. Kurniasih, C. Hasyim, A. Wulandari, M. I. Setiawan, and A. S. Ahmar, "Comparative Case Studies on Indonesian Higher Education Rankings," in Journal of Physics: Conference Series, 2018, vol. 954, no. 1, p. 12021.

[11] M. I. Setiawan et al., "E-Business, The impact of the Regional Government Development (APBD) on Information and Communication Development in Indonesia," in Journal of Physics: Conference Series, 2018, vol. 1007, no. 1, p. 12045.

[12] M. I. Setiawan et al., "The Correlations between Airport Sustainability and Indonesian Economic Growth," in IOP Conference Series: Earth and Environmental Science, 2018, vol. 140 , no. 1, p. 12089. 